\title{
Internet Access and the Potential in Facilitating Online Political Communication of Disabled
}

\section{Akses Internet dan Potensinya dalam Memfasilitasi Komunikasi Politik Online Difabel}

\author{
Nurul Hasfi ${ }^{1}$, Joyo NS Gono², Wiwid Noor Rakhmad ${ }^{3}$ \\ ${ }^{123}$ Departemen Ilmu Komunikasi Undip, Jl. Prof Soedarto Tembalang Semarang \\ nurul.hasfi@live.undip.ac.id ${ }^{1}$,jnsgono@gmail.com ${ }^{2}$,wiwidfisip@gmail.com ${ }^{3}$
}

\begin{abstract}
Internet was conceived by many researchers as a medium that was capable of resolving the social exclusion of groups of people with diffability. The internet penetration rate in Indonesia that always increased ideally should be a sphere for people with diffability to realize an inclusive election. However, in Indonesia, the dominant group, in this case, non-diffabled, were still taking control of the virtual space. The research aimed to understand the potential of the internet as a medium for online political participation of groups with diffability. By applying a case study in the context of the 2018 Gubernatorial Election of Central Java, this research conducted in-depth interviews with people with diffabilities, the election organizers (KPU, BAWASLU) and educational institutions. The research found that particular groups of people with diffability (vision impairment, hearing loss, and mild intellectual retardation) in Semarang had had access to the internet. However, internet access had not yet provided the diffabled group access to the online communication process. In other words, the internet had not figured in being assistive technology (AT) for realizing online political participation for the diffabled. The leading possible cause was the digital divide that was contributed by both the internal problems, such as skepticism to politics, anti-polarization in the online discussions, and the external problems, including the low quality of the internet literacy for the diffabled.
\end{abstract}

Keywords: Internet access, people with diffability, online political communication, inclusive elections

\begin{abstract}
Abstrak
Teknologi termasuk internet disebut para peneliti sebagai medium yang mampu mengatasi ekslusi sosial (social exclusion) kelompok difabel. Penetrasi internet di Indonesia semakin meningkat seharusnya menjadi ruang bagi kelompok difabel untuk mewujudkan pemilu inklusif. Namun, dalam konteks Indonesia kelompok dominan non-difabel masih menguasai ruang virtual. Tulisan ini ingin memahami potensi internet sebagai sarana partisipasi politik online kelompok difabel. Dengan menggunakan metode studi kasus dalam konteks Pilgub Jateng 2018, penelitian ini melakukan wawancara mendalam dengan difabel, penyelenggara pemilu (KPU, Bawaslu) dan institusi pendidikan di Kota Semarang. Penelitian ini menemukan difabel (fisik dan grahita ringan) di Kota Semarang telah memiliki akses terhadap internet, namun akses internet ternyata belum memberikan difabel akses berkomunikasi. Artinya, internet belum berfungsi sebagai Assistive Technology (AT) untuk sarana partisipasi politik online karena adanya digital divide yang bersumber dari masalah internal seperti skeptisme difabel terhadap politik; anti-polarisasi dalam diskusi politik online dan eksternal yakni karena rendahnya literasi internet bagi difabel. Kata Kunci: akses internet, difabel, komunikasi politik online, pemilu inklusif
\end{abstract}




\section{Introduction}

Internet consumption in Indonesia increases every year. According to APJII (APJII, 2018 ), the internet penetration rate in Indonesia has reached 171,17 or $64,8 \%$ of Indonesia's total population, or equal to 268,16 million people. Together with a rising percentage of internet users accounting for $10.12 \%$ annually and the increasing number of internet infrastructure developed by the government, Indonesian internet users, including with social media users, are skyrocketing. In the context of Indonesian election and politics, this trend plays a significant role in the development of democracy (So do in other parts of the worlds (Dahlberg, 2001; Van Dijk, 2012)) even though social media are frequently deemed an artificial democratic sphere (Hasfi, Usman, \& Santosa, 2017) or merely a room for grooming hate speech (Lim, 2017) which degrade democratic process. For example, In Indonesia, marginal groups, including young voters, although their political participation has not utterly been scrutinized (Perangin-angin \& Zainal, 2018), and "diffabled people" (Indonesian word for disabled groups), as the research will explore, have used social media massively to participate in political activity.

Nevertheless, many marginal groups, including the people with diffability, have not obtained a sufficient communication opportunity, apart from the fact that the internet has been a sphere of freedom of expression and has been enjoyed by the majority of Indonesian people. To address that problem, the researchers follow Papacharissi (2002) that categorized the internet as one of the public spheres with the conception of the virtual public sphere. That framework enables the researchers to defines the internet as a virtual public sphere that can be an alternative sphere for the diffabled groups to voice their interests. In that vein, the internet is essential since traditional public spheres provided by conventional media in Indonesia has been stirred by economic and political interests (Armando, 2014); (Nugroho, Putri, \& Laksmi, 2012); (Sudibyo \& Patria, 2013); (Papacharissi, 2002). It makes the real function of the public sphere be shifted

As regards Indonesian political lives, recognition towards equality for the diffabled groups has been ratified in Law No. 7, Paragraph 5, 2017 concerning the election. The law allows diffabled people to be voters, candidates of representative, senate, and presidency, as well as the organizers of the election. Diffabled or "differentlyabled" means people that have special abilities. That definition emphasizes the can-do aspect of having a disability (Maftuhin, 2016). Because of that, the researchers used the words diffabled and diffability instead of the standard version of the disabled although Indonesian national Law No. 8, 2016, still mentions the diffabled as disabled. It is defined as anyone that has a physical, intellectual, mental and sensory limitation in a quite long time and thus halting their interaction with their environment and other citizens with the same right effectively and utterly

It is essential to see the function of the internet as a medium to facilitate the limitation of the diffabled in expressing their opinions. The researchers see the internet as a means to assist the diffabled, as stated in Indonesian Law No. 8, 2016. The law asserts that a diffabled tool is a tool figuring in aiding diffabled people in completing their tasks. This assistance tool is a technology that, in the theoretical discussion, is called the Assistive Technology (Owuor, Larkan, \& MacLachlan, 2017). These tools are any product and service that can be used by people with diffability to solve their daily problems, including glasses, hearing aid, and wheelchair. Furthermore, the advocate of this technology emphasized that people with diffability that have access to assistive technology can transform a community that is concerned with groups with intellectual diffability. Access of technology that is open towards them will empower and create 
social inclusion for the diffabled. Conversely, limited access can constrain the social process of the diffabled and provoke social exclusion. That is to say, the more accessible the internet, the more inclusive the diffabled groups in elections.

Many studies on the Indonesian election and the diffabled groups have been conducted, but they mostly emphasized the offline activities, notably regarding the limited infrastructure for this marginal group (I Gusti Gede Made Gustem Lasida, 2017); (Dewi, 2013); (Halalai, 2016). A worth noting study is a study carried out by Gustomy (2017) that used five forms of political participation concepts, namely organization, elections, contacting, violence, and lobby, to map the pattern of diffabled group participation. The research found a discrepancy between action and awareness of political participation. As a result, the participation of groups with diffability was not sufficient in affecting public policies. Merly (2016), on the other hand, focused on law discrimination and depicted unsatisfying scores from the respondents regarding the physical accessibility of the diffabled. Consequently, the government was considered unsuccessful in manifesting an accessible election.

Meanwhile, in other countries (outside Indonesia), the investigation of the diffabled participation in politics has started to focus on the adoption of information and communication technology (ICT). There are several worths noting studies regarding this topic. Firstly, a study conducted by Sourbati (2012) identifying social inclusion or einclusion of the diffabled groups in the UK. The study concluded that government policies in promoting internet access to this group were still not ample. Furthermore, there was Rubaii-Barrett \& Wise (2008) research that examined the e-government for the diffabled groups in the USA that guaranteed information availability for the diffabled groups. They identified different responses of each state to fulfill the needs of individuals with diffability in the policies. Schur, Shields, Kruse executed another investigation studying participation rate of the diffabled voters by surveying 700 voters with diffability and 1240 voters without diffability. This survey revealed that the number of diffabled voters was twenty percent less participative than the voters without diffability. The proposed causes were sociological and psychological. The other study was done by Ward, Baker, \& Moon (2009) that saw discrimination towards diffabled voters conducted by the organizers of the election hindrance the process of the group to vote. It ranged from the inaccessible polling places, unsupportive law and policies, and difficulty in employing e-voting.

Although the studies mentioned have studied about the diffabled, technology, and election, a particular investigation on the potential of the internet for people with diffability in encouraging inclusive election was still limited. By identifying the accessibility of groups having different abilities and internet roles in online political communication in the Central Java Gubernatorial Election 2018, this research describes the internet potential in facilitating election that was inclusive on the diffabled groups. The research answers three primary questions, namely, how is the internet accessibility of disabled groups? What is the potential toward the diffabled groups' capability in participating in the online discussion, and what are the challenges that should be faced by the diffabled group in performing online political communication?

\section{Methodology}

The research applied a case study method of Robert K. Yin (Ridder, 2012) to explore internet accessibility of people with diffability in Semarang and its potential in establishing the online political participation of the Diffabled in the Gubernatorial 
Election 2018 of central java in Semarang city. The research was split into two steps, data collection, and data analysis.

For data collection, the researchers (a) interviewed people with diffability in Semarang who already had suffrage. The research limited the interviewees to people with physical diffability, mild intellectual retardation, and who had vision impairment. These people came from various non-government organizations, including LSM Roemah Difabel, Persatuan Tuna Netra Indonesia (Pertuni), LSM Sahabat Mata, Persatuan Penyandang Difabel Indonesia (PPDI) Central java, and Paguyuban Difabel Sehati. Also, the researchers interviewed teachers and students with diffability in Yayasan Penyandang Anak Cacat (YPAC) Semarang, as well as KPU (the General Election Committees) Central Java, as the organizer of the election, and Bawaslu (the Election Supervisory Agency) Central Java. In addition, (2) observation was also performed in LSDM Roemah Difabel and YPAC Semarang, together with (3) focus group discussion (FGD) to 15 diffabled people who were under the supervision of the Election Supervisory Agency of Central Java.

The data was analyzed by first creating categories. It then was argued in the narrative that can answer research questions. The data was obtained from questions given to the informants that were designed by considering two primary indicators of the research: internet accessibility and forms of political participation that was possible to be carried out by people with diffability.

\section{Results and Discussion}

This part will describe the finding of the research that consists of three main topics, descriptions about the internet access for people having diffability in Semarang; the forms of online participation they carried out with their access; and challenges they face, as well as the possible causes.

The research referred to the indicators of barriers to accessing the internet typically faced by children and vulnerable groups to identify the accessibility of people with diffability. The standards were made by United Nations Special Rapporteur (UNICEF, 2017), and five main points are listed as barriers. The first is the affordability barrier or a challenge that comes from the high cost of internet access. This barrier halts diffabled groups to invest in ICT, such as a mobile phone and the data. Another challenge is connectivity. This stems from insufficient communication connectivity and the gap in electricity infrastructure in rural and urban areas. The third problem is literacy or level of technical skill that is typically low in accessing the internet. Discrimination is accounted for another challenge since negative stereotype to the people with diffability is still endemic. The other barrier is inclusivity. It can be seen from the design of the technology itself that is not diffabled-friendly that they commonly face difficulty to conduct the online activity.

On the other hand, for examining online political communication, the research appropriated the conception of online political participation of Yang \& DeHart (2016) that identified online political participation, especially after the advent of social media, as a part of online political communication. For Yang \& DeHart, that participation includes sharing opinion and political interest on social media, discussing in the social media groups and hashtag \# on Twitter or Pinterest, forwarding retweeting and tweeting political affiliation, writing on a blog, and creating videos on YouTube regarding political aspirations. Numerous studies have admitted social media potential in online political participation. The research also employes Gil de Zúñiga, Molyneux, \& Zheng (2014) to 
identify the activities of online political participation that is more active. It can range from writing aspirational articles to politicians on the internet, initiating political campaigns through the internet, subscribing to the political discussion of politicians, involving as a volunteer in a campaign and political debate in cyberspace, writing an article to online media editorial.

Table 1 below is the summary of the main finding of the research. There are three primary issues, on the accessibility of people with diffability, the implication in the online political participation of the Diffabled, including the potential, and the challenges that appeared in the civic engagement.

Table 1 Internet accessibility and online political participation of the Diffabled (Source: in-depth interview)

\begin{tabular}{|c|c|c|}
\hline Internet accessibility & $\begin{array}{c}\text { Online political participation of } \\
\text { the people with diffability }\end{array}$ & $\begin{array}{c}\text { Barriers in online } \\
\text { political participation }\end{array}$ \\
\hline $\begin{array}{l}\text { affordability: } \\
\text { be able to access: } \\
\text { - Laptop } \\
\text { - Mobile phone } \\
\text { - Computer }\end{array}$ & \multirow{5}{*}{$\begin{array}{l}\text { - Dominant in using a mobile } \\
\text { phone } \\
\text { - Reading, sharing, and } \\
\text { commenting on political news } \\
\text { in the WA group of the } \\
\text { Diffabled. } \\
\text { - Reading campaign post on } \\
\text { social media } \\
\text { - Following the account of the } \\
\text { desired governor and vice } \\
\text { governor candidates. } \\
\text { - Liking the candidate posts } \\
\text { - Discrimination is more in } \\
\text { real-life }\end{array}$} & \multirow{5}{*}{$\begin{array}{l}\text { - Uninterested in giving } \\
\text { commentary on politic, } \\
\text { and prefer to run a } \\
\text { business, have a } \\
\text { relationship, and } \\
\text { provide support. } \\
\text { - There was an offline } \\
\text { political participation } \\
\text { so-called relawan } \\
\text { demokrasi (Relasi) } \\
\text { (democratic } \\
\text { volunteer). However, it } \\
\text { did not use the } \\
\text { internet. } \\
\text { - There were still people } \\
\text { with diffability who } \\
\text { could not access the } \\
\text { internet, notable } \\
\text { people with intellectual } \\
\text { diffability, both mild } \\
\text { and severe, and with } \\
\text { mental diffability. } \\
\text { - There were ICTs } \\
\text { available for } \\
\text { Gubernatorial Election } \\
\text { 2018, such as } \\
\text { Diffabled-friendly } \\
\text { KPU's website, } \\
\text { SWARA application, } \\
\text { but there was not } \\
\text { literacy activity on the } \\
\text { function of the web } \\
\text { and the app. }\end{array}$} \\
\hline $\begin{array}{l}\text { Connectivity } \\
\text { - Media habit: social media } \\
\text { (FB, IG, Twitter, Blog, } \\
\text { Youtube) }\end{array}$ & & \\
\hline $\begin{array}{l}\text { Discrimination } \\
\text { - No discrimination } \\
\text { experienced while expressing } \\
\text { political aspiration online. } \\
\text { The Diffabled group felt freed } \\
\text { to express themselves. } \\
\text { - People with diffability who } \\
\text { could access: people with } \\
\text { impaired vision, deaf, } \\
\text { physical diffability, and } \\
\text { intellectual retardation. }\end{array}$ & & \\
\hline $\begin{array}{l}\text { Inclusivity } \\
\text { - The availability of free } \\
\text { application of communication } \\
\text { aid for people with physical } \\
\text { diffability, such as vision and } \\
\text { hearing impairment, and mild } \\
\text { intellectual retardation. }\end{array}$ & & \\
\hline $\begin{array}{l}\text { Literacy } \\
\text { - The availability of free } \\
\text { application as a } \\
\text { communication aid }\end{array}$ & & \\
\hline
\end{tabular}


- The literacy of ICT for

the Diffabled was still

for helping a living,

such as excel and

selling online web

People with diffability have internet access, yet not involved in political discussion

Firstly, the affordability indicator is defined as the capability of the diffabled to access the internet. It is highly linked with the cost they should spend for personal use and the facilities that have been provided by the government. The finding showed that people with diffability had reached the internet through their gadgets, including laptops, personal computers, and mobile phones, as the most frequent device used.

Based on the researchers' observation in YPAC Semarang, almost all informants with mild intellectual retardation was given a mobile phone by their parents, and the gadgets could be brought to the school. Occasionally, in the break time, the teacher allowed the students with diffability to use the internet, notably for entertainment, such as YouTube and game. From four informants with mild intellectual retardation, there was only one informant who did not own a mobile phone because of financial issues. The other three were purchased mobile phone by their parents. Each month, they spent about Rp30.000 to Rp50.000 on internet data.

Novi, the caretaker of Roemah Difabel, firmly stated that most of the Diffabled in Semarang had been connected with the internet through their gadgets. Roemah Difabel, Sahabat Mata and Persatuan Tuna Netra Indonesia (Pertuni), and Persatuan Penyandang Disabilitas Indonesia (PPDI) in Semarang city observed that around 70\% of their members had been capable of accessing information through the internet. Roemah Difable that had social media account even had a laptop for daily operation. The laptop was a gift from the governor of Central Java, Ganjar Pranowo.

What the Diffabled people carried out with their gadget was, firstly, according to Basuki, the leader of LSM Sahabat Mata, to interact with other people on social media. However, they rarely used it for political discourse. It is in agreement with Novi, an organizer of Roemah Difable, that confessed that her pupils refused to post political issues. In YPAC, a diffabled person by whom the researcher interviewed opined that "political discourse is replete with bigotry, and I do not like it." Out of the diffabled people that the researchers asked to discuss, whether in the FGD or in-depth interview, mentioned that online political participation as a passive activity, such as, as what was identified by Yang \& DeHart (2016), like, share, and retweet. In the Gubernatorial Election of Central Jawa, there were no people with diffability that were involved in the process of comprehensive opinion presentation, such as writing an article, criticizing, or commenting, as mentioned by (Gil de Zúñiga et al., 2014). It means that the diffabled, despite accessing the internet, has not wished yet to engage with comprehensive political discussion in the cybersphere.

Secondly, connectivity indicator is defined as the availability of the internet infrastructure, which, in this case, is in Semarang city. Like other metropolises, internet infrastructure in Semarang had given high-speed access towards the diffabled. It was different from the rural areas that put up with connectivity issues. The sufficient internet availability in Semarang was confirmed by Novi, an organizer of Roemah Difabel. For her, the diffabled was supported by the parents that provided a smartphone that was 
brought independently. Consequently, they could access the internet, whether in their house, school, or in Roemah Difabel. On the other hand, according to Yayasan Penyandang Anak Cacat (YPAC), Semarang, people with mild intellectual retardation had also used a smartphone to the school and used it in the break time between subject to play a game and watch video on YouTube. The teachers mentioned that internet accessibility was essential to keep them not bored during the teaching-learning process. Because of that, Novi tended to opine that people with diffability in Smearang was more flexible in accessing information through the internet compared to their colleagues in rural areas. This description that the diffabled in the city was easier to get internet access was confirmed by Ahyani, an organizer of Persatuan Tuna Netra Indonesia (Pertuni) Central Java that mentioned that more than sixty percents of the members had been capable of using the internet using the smartphone.

To describe the media habit of the diffabled in Semarang, the researchers intensely interviewed people with diffability in rural areas. Dany, the secretary of Persatuan Penyandang Difabel Indonesia (PPDI), Sukoharjo Regency, mentioned that, as opposed to people with diffability in Semarang, internet access of the diffabled in Sukoharjo was lower. He said that the description of internet access in PPDI Sukoharjo only accounted for $20 \%$ of the total members. The most possible cause was external, namely limited infrastructure, such as poor connections in the rural areas. Also, the internal factor affected up to a point, such as the low economic capability to purchase communication aid, such as smartphones, laptops, and internet data.

Thirdly, the discrimination indicator is defined by Macionis (2012: 328) as a different treatment towards the different human categories. Discrimination is close to prejudice, but the differences mostly lie in action. Whereas discrimination is close to the action, prejudice to attitude. Discrimination can be harmful if it is used to halt other people. The research showed that there was technical and indirect discrimination towards the diffabled, such as access, affordability, and literacy that was not equal and fair. Take this passage as an example:

We do not know where to access information on elections. No one informs us, and we do not know to whom we have to ask (Basuki, Sahabat Mata).

This firm statement was contended by Basuki, from LSM Sahabat Mata. Yani, from LSM Sehati Surakarta, also experienced the same treatment. She informed the researchers that her members did not have sufficient information on the election of Central Java 2018. She also said that not many of the members of Sahabat Mata that accessed information of the election because of limitation in the infrastructure. Basuki added that he was pessimistic with the emancipation of diffabled people in cyberspace since discrimination in the real-life had not even been eradicated and still on-going.

However, in the middle of the diffabled people's reservations that have limited access, they also admitted that the internet had made them more free in showing their expression. Although some of them were afraid of the Indonesian Law of Information and Electronic Transaction (UU ITE), they confessed that their relationship with broader society was more flexible and comfortable. They also were more confident in communicating with the non-diffabled group on the internet since the internet did not enable other people to see their condition. Internet, therefore, is capable of ending one of the most significant barriers in the social inclusion process of diffabled people, who by 
far always bear negative stereotypes in Indonesia. If so, the internet's potential in establishing an inclusive election is crucial.

According to Basuki, the leader of LSM Sahabat Mata, the most challenging barrier for people with diffability includes cultural barriers, namely negative stereotypes towards people having diffability as abnormal. Arguably, that perspective was institutionalized and had become a mechanism that ruled the citizens. The consequence was malpractice in the manifestation of democracy that discriminates people with diffability. Besides, discrimination stemmed from the attitude of the family that embarrassed to bring their family members that were diffabled to election places because of the stereotype that diffabled people was a shame.

Based on the finding above, the researchers saw that discrimination in the reallife towards the diffabled people can be minimized by taking advantage of technology, which in this case is the internet. Apart from the fact that more and more people with diffability can access the internet, the internet has the potential to eradicate negative stereotypes in society towards the diffabled. It means that Owuor et al., (2017) theory on assistive technology can help to create diffabled inclusivity.

Fourthly, the inclusivity indicator discusses how information and communication technology ease people with diffability to be involved in internet political participation. Based on the in-depth interview, many people with diffability were happy with the increasing number of free applications figuring in being communication assistive technology, as shown in Table 2 below. According to Ahyani, a person with impaired vision from LSM Pertuni, most diffabled people in Semarang had employed various ICT in the forms of diffabled-friendly software that was available on Google Playstore. The software was to help people to be connected with the internet. The followings are the software that was frequently used by the diffabled people in Semarang.

Table 2. Technology Infrastructure and accessibility owned by the diffabled people (source: in-depth interview and literature review)

\begin{tabular}{|c|c|c|c|}
\hline $\begin{array}{l}\text { Type of } \\
\text { diffability }\end{array}$ & Accessibility & General infrastructure & $\begin{array}{c}\text { Special infrastructure for } \\
\text { Gubernatorial Election } 2018\end{array}$ \\
\hline Hearing loss & Able to access & $\begin{array}{l}\text { - Free apps on the } \\
\text { internet (Google play } \\
\text { store) }\end{array}$ & $\begin{array}{l}\text { Diffabled-friendly website } \\
\text { (KPU Central Java) }\end{array}$ \\
\hline $\begin{array}{l}\text { Vision } \\
\text { impairment }\end{array}$ & Able to access & $\begin{array}{l}\text { - Free apps on the } \\
\text { internet (Google play } \\
\text { store) }\end{array}$ & $\begin{array}{ll}- & \text { Free app Swara provided by KPU } \\
\text { Central Java (Google play store) } \\
\text { - } \\
\text { Diffabled-friendly website } \\
\text { (KPU Central Java) }\end{array}$ \\
\hline Physical & Able to access & - Voice command & - Not available \\
\hline Rungi & Able to access & - Not demanding & - $\quad$ Not available \\
\hline $\begin{array}{l}\text { Mild } \\
\text { intellectual } \\
\text { retardation } \\
\end{array}$ & $\begin{array}{l}\text { Able to access } \\
\text { with supervision }\end{array}$ & - Not yet invented & - $\quad$ Not available \\
\hline $\begin{array}{l}\text { Medium } \\
\text { intellectual } \\
\text { retardation }\end{array}$ & $\begin{array}{l}\text { Incapable of } \\
\text { accessing }\end{array}$ & & - $\quad$ Not available \\
\hline $\begin{array}{l}\text { Severe } \\
\text { intellectual } \\
\text { retardation }\end{array}$ & $\begin{array}{l}\text { Incapable of } \\
\text { accessing }\end{array}$ & & - $\quad$ Not available \\
\hline
\end{tabular}


People with impaired vision had many assistive tools available on the internet, such as screen reader, spoken-web that enable them to browse. Also, there were numerous free applications, such as VoiceOver (iPhone), TalkBack, RogerVoice, Commandr for Google Now, The Deaf and Hearing Impaired (Google), that converted a text to be a voice. In Indonesia, similar apps had also developed, such as MAS Jawa T-Netra and Ayobaca.id. Similarly, an app for people with hearing loss had also been developed and had been available for free in the Google play store. One of them was Roger Voice figuring in making a call, and it had been compatible with both smartphones and tablets. Another app was the Deaf and Hearing Impaired, and the function was to people with loss hearing by appearing vibration and flashlight on the smartphone when there was a voice around the smartphone owner. The deaf communicator was also an app that was used by the researchers in this research to read a message from their mobile phones and WhatsApp. For people with physical diffability in Indonesia, they already had an opportunity to be equipped with an app called voice-command, developed by Telkomsel.

With the availability of assistive technology as an online communication aid, although it had not been available for all groups of diffabled, the lists showed that there was significant potential showing that diffabled groups could access information and was involved in online communication. The question is that: do the people with diffability have skills in operating the tools? It will be answered in the following section of literacy.

Fifthly, although affordability and connectivity indicators have demonstrated that the internet accessibility of people with diffability did not undergo any severe obstacle, in internet literacy indicator, the availability of internet access of people with diffability in Semarang toward information on the Gubernatorial Election was still low. Literacy that is understood here is a) the capability of the diffabled groups in technically accessing the internet and $b$ ) the understanding of the groups regarding the importance of the internet for online political participation and the significance of their potential intellectually to be involved in online political participation. The last point was mentioned by Jaeger (2009) as the accessibility of diffabled groups towards communication and not only information.

Overall, although the finding showed that internet literacy in the first point had not been developed yet, there was a significant potential that could be designed to increase communication access because of the better internet infrastructure, such as internet network availability and free tools of information technology. On the other hand, the research affirmed that diffabled literacy on the advantages of the internet as a facility to be active in political participation was still low.

As regards the capability of accessing the internet, the research found that diffabled people were still facing limitations. Out of many types of diffability, they that could access the internet were people with loss hearing, vision impairment, physical diffability, and mild intellectual retardation. On the other hand, medium and severe intellectual retardation was facing obstacles out of mental limitations.

The interviews that were done towards students of YPAC, Semarang, who had mild intellectual retardation, showed that they were familiar with gadgets, such as a smartphone. They could use media messenger or social media to communicate with other students, diffabled community, teachers in their schools, or family. Nevertheless, they never used it actively for accessing information regarding politics or the Gubernatorial Election of Central Java 2018, or other election activity.

As for internet use as a tool for the socialization of Gubernatorial Election of Central Java 2018, KPU Central Java had provided a diffabled-friendly website and a free 
app that can be downloaded on Google Store named SWARA. SWARA was an app that won a competition held by KPU Central Java as the attempt to socialize information regarding election to people with diffability.

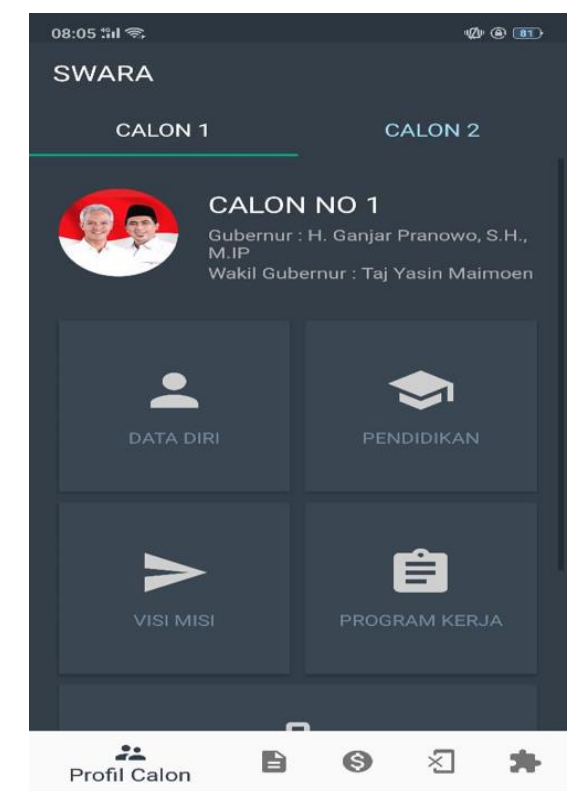

Figure 1 SWARA app for Gubernatorial Election 2018

SWARA application contained information on the profile of two candidates, namely Ganjar-Yasin and Sudirman-Ida. It consists of biography, education, vision and mission, work experience, and career. The application was mainly designed to help people with vision impairment. It was equipped with a program that can help the users to read the text. Also, there was a chat room that enabled users to discuss.

Nonetheless, in its attempt to facilitate internet infrastructure for diffabled people, KPU Central Java has not been supported by a structured socialization system. Consequently, it was not accurate on target. On the other hand, KPU's website was equipped with software that enabled people with impaired vision to access KPU. This website provided a list of registered diffabled voters in Central Java.

Based on the informants' confession, all informants had not found out about SWARA app and the diffabled-friendly website mentioned by KPU. KPU Central Java itself admitted that there was no unique socialization towards people with diffability through information technology, which in this case, internet, for Gubernatorial Election purpose. However, KPU Central Java stated that they had involved diffabled groups in offline socialization. One of them was with democratic volunteers or RELASI. Some of the informants from diffabled LSM affirmed that they were active in that democratic volunteer.

The research found that people with diffability had low literacy regarding the advantages of the internet as the encourager of online political participation for their groups. No informant mainly used the internet for online political participation in the context of the Gubernatorial Election of Central Java 2018. The organizer of Roemah Difabel, Semarang, Novi confirmed that there was no online socialization on Gubernatorial Election of Central Java 2018 for communities of people with diffability in Semarang through the internet. She, however, also confirmed that KPU Central Java 
had done offline socialization. With a different perspective, Basuki, a person with vision impairment and founder of Komunitas Sahabat Mata in Semarang, contended that socialization activity conducted was still merely formality for finishing the election agenda. Attempts in facilitating the needs and interests of people with diffability in the election had not been found.

\section{Digital Divide as the barriers of diffabled people in establishing inclusive election}

Although people with diffability had accessed the internet, they had not been seen involved in online political participation, except for click-activism (Lim, 2002). Although in this context click-activism is different from what theorized by Lim since it is closer to the incapability of diffabled people in using the internet. The finding of this research corroborated the reservation of Jaeger (2009) that focused on the online political participation of vulnerable groups of diffabled people. It suggests that what is needed now is not only internet accessibility but also their involvement in the internet. The argumentation is based on this finding:

Firstly, people with diffability has not used the internet as a tool for democracy. Rather, they used it for: a) informing daily activity that was done in and by the LSM; b) extending contact lists and building a friendship with other diffabled people through social media; c) supporting each other as the same minority group; d) running business or selling products.

The political participation of diffabled people was done in the real-life (offline). The first activity was involved in the socialization held by KPU Central Java through democratic volunteers or RELASI and attending in the socialization of Gubernatorial Election held by Bawaslu Semarang and KPU Central Java. This activity was done, for example, by Ahyani, from Persatuan Tuna Netra Indonesia (Pertuni). She actively was involved by socializing the Gubernatorial Election 2018 to her networks consists of people with diffability in Central Java. The same activity was done by diffabled people that attended Bawaslu Surabaya to be involved in the election socialization. Another activity was following socialization that was held by KPU and Bawaslu Central Java. Nevertheless, socialization that was done was still not adequate and continuous. Although KPU special division regarding socialization towards diffabled people, there was no unique strategy to maximize the result of socialization by using the internet. One of the commissioners of KPU Central Java said that KPU did not have an obligation to provide internet access to diffabled people to access information on the Gubernatorial Election of Central Java 2018.

Secondly, the research showed that intended political communication intended reflected from online political participation of diffabled groups in Semarang had not been experienced in the Gubernatorial Election of Central Java 2018. Consequently, the internet, that has been argued by researchers as media that replace tradition media in communication process because of the new characteristics (Dahlberg, 2011); (Van Dijk, 2012); (Papacharissi, 2004), has not been justified to be a facilitator that can encourage inclusive election in Semarang. This research affirmed that the internet has not functioned as subaltern counter-public (Fraser, 1993) or a room that can be used by a minority group (diffabled group) as a tool to strive for their right in the political process. Also, the internet has not been an assistive technology in the definition of (Owuor et al., 2017) since it has not been a tool for social inclusion of people with diffability. 
The identification towards the potential of accessibility of diffabled people that is not supported with sufficient online political participation leads the research to the argumentation of the digital divide (Macdonald \& Clayton, 2013). It is a gap appearing between those who have access and capability of using ICT and those who do not. In this context, it is a gap between the group of diffabled people and non-diffabled, and at some point among the groups of diffabled people themselves.

The digital divide that is meant in this research can be seen from several factors. Firstly, limitation in infrastructure and unequal opportunity in internet use. The latter happened because of geographical position, such the differences in facility between urban and rural areas, financial issues of the diffabled so that they cannot afford gadgets, such as laptop, mobile phone, or data, and inaccessibility of assistive technology, such as software, that can ease they who did not reach in online political participation.

Secondly, the low awareness of the diffabled in finding out the source of information regarding the election. It is ironic since when non-diffabled was poured by the information about the election of Central Java's governor, a group of diffabled people did not even know where they should access the information. Thirdly, the contents of the Gubernatorial Election of Central Javo 2018 on the internet was reasonably ineffective for supporting diffabled need. Finally, many diffabled people were not aware and conscious of the advantages of the internet to emancipate equality for their political rights.

The finding of the digital divide in the communities of diffabled is in line with the argument of Macdonald \& Clayton (2013) that mentioned that digital technology, which is intended to address social exclusion, brings new obstacles for the diffabled, namely digital divide. This research suggests that the digital divide between diffabled and nondiffabled people and among diffabled communities themselves for manifesting online political participation is one of the most demanding jobs for Indonesia as a nation. It occurred since not only was this perspective not be used to create a better environment for the diffabled, but also many offline, real-life, problems were not solved yet.

\section{Conclusion}

The research has demonstrated that some people with diffability had accessed the internet, especially in terms of affordability, connectivity, inclusivity, that was the potential to create inclusive election. Indeed, the discrimination indicator has shown that the internet had eradicated the comfortability problem in communication, which was usually put up with the diffabled, by making people in the cybersphere not focus on the negative stereotype. Nevertheless, diffabled had not owned communication accessibility, and online political participation since the literacy barrier and some elements in discrimination were still alive. The activity of political involvement on the internet was still passive, such as reading information and performing click-activism (love, share, like), and they had not developed public opinion to support their interests.

The research concludes that those problems were caused by the digital divide that included the low level of internet literacy rate and the low level of available media socialization. Based on this research, the researchers recommend that the election organizers, KPU and Bawaslu, and other elements of society who care about democracy be more considerate of barriers put up with the diffabled people. Programs that could be done to support inclusive election is internet literacy for diffabled. This program should focus on the advantages of the internet as assistive technology, as a medium that is capable of facilitating their sense limits in delivering their political aspirations independently. 


\section{References}

APJII. (2018). Penetrasi \& Profil Perilaku Pengguna Internet Indonesia. In Apjii.

Armando, A. (2014). The greedy giants: Centralized television in post-authoritarian Indonesia. International Communication Gazette. https://doi.org/10.1177/1748048514524106

Dahlberg, L. (2011). Re-constructing digital democracy: An outline of four "positions." New Media and Society. https://doi.org/10.1177/1461444810389569

Dewi, P. R. K. (2013). AKSESIBILITAS PARTISIPASI POLITIK PENYANDANG DISABILITAS DALAM PEMILU DI KOTA DENPASAR Putu. Https://Repositori.Unud.Ac.Id.

Fraser, N. (1993). Rethinking the Public Sphere: A Contribution to the Critique of Actually Existing Democracy (pp. 109-142). pp. 109-142. Routledge.

Gil de Zúñiga, H., Molyneux, L., \& Zheng, P. (2014). Social media, political expression, and political participation: Panel analysis of lagged and concurrent relationships. Journal of Communication. https://doi.org/10.1111/jcom.12103

Gustomy, R. (2017). Partisipasi Politik Difabel Di 2 Kota. IJDS : Indonesian Journal of Disability Studies, 4(1), 51-62. https://doi.org/10.21776/ub.ijds.2017.004.01.8

Halalai, M. R. (2016). Pemenuhan Hak Politik Penyandang Disabilitas Sesuai Dengan Undang-Undang Nomor 8 Tahun 2016 Tentang Penyandang Disabilitas Oleh Komisi Pemilihan Umum ( Kpu ) Kota Yogyakarta Skripsi Diajukan Kepada Fakultas Syar I'Ah Dan Hukum Universitas Islam Negeri S. PROGRAM STUDI ILMU HUKUM FAKULTAS SYARI'AH DAN HUKUM UNIVERSITAS ISLAM NEGERI SUNAN KALIJAGA YOGYAKARTA.

Hasfi, N., Usman, S., \& Santosa, H. P. (2017). Representasi Kepemimpinan Calon Presiden Di Twitter. Jurnal ASPIKOM, 3(2), 270-284.

I Gusti Gede Made Gustem Lasida. (2017). MEMBANGUN PEMILU INKLUSIF UNTUK DIFABEL (Studi Kasus Pilwali Kota Yogyakarta 2017). Repository.Unair.Ac.Id.

Jaeger, P. T. (2009). Developing Online Community Accessibility Guidelines for Persons With Disabilities and Older Adults. Journal of the American Society for Information Science, 55-63. https://doi.org/10.1177/1044207308325997

Lim, M. (2017). Freedom to hate: social media, algorithmic enclaves, and the rise of tribal nationalism in Indonesia. Critical Asian Studies, 49(3), 411-427. https://doi.org/10.1080/14672715.2017.1341188

Macdonald, S. J., \& Clayton, J. (2013). Back to the future, disability and the digital divide. Disability and Society. https://doi.org/10.1080/09687599.2012.732538

Maftuhin, A. (2016). Mengikat Makna Diskriminasi: Penyandang Cacat, Difabel, dan Penyandang Disabilitas. INKLUSI. https://doi.org/10.14421/ijds.030201

Merly, M. (2016). Aksesabilitas Pemilu 2014 dan Implikasinya terhadap Ketahanan Politik (Studi Tentang Persepsi Mahasiswa Penyandang Disabilitas Di Pusat Layanan Difabel UIN Sunan Kalijaga Yogyakarta). Jurnal Ketahanan Nasional. https://doi.org/10.22146/jkn.8123

Nugroho, Y., Putri, D. A., \& Laksmi, S. (2012). Mapping the Landscape of the Media Industry in Contemporary Indonesia. In Report series: Engaging Media, Empowering Society: Assessing media policy and governance in Indonesia through the lens of citizens' rights.

Owuor, J., Larkan, F., \& MacLachlan, M. (2017). Leaving no-one behind: using 
assistive technology to enhance community living for people with intellectual disability. Disability and Rehabilitation: Assistive Technology. https://doi.org/10.1080/17483107.2017.1312572

Papacharissi, Z. (2002). The virtual sphere: The internet as a public sphere. New Media and Society. https://doi.org/10.1177/14614440222226244

Papacharissi, Z. (2004). Democracy online: Civility, politeness, and the democratic potential of online political discussion groups. New Media and Society. https://doi.org/10.1177/1461444804041444

Perangin-angin, L. L. K., \& Zainal, M. (2018). Partisipasi Politik Pemilih Pemula Dalam Bingkai Jejaring Sosial Di Media Sosial. Jurnal ASPIKOM, 3(4), 737. https://doi.org/10.24329/aspikom.v3i4.210

Ridder, H.-G. (2012). Yin , Robert K .: Case Study Research . Design and Methods. Zeitschrift Für Personalforschung.

Rubaii-Barrett, N., \& Wise, L. R. (2008). Disability access and e-government: An empirical analysis of state practices. Journal of Disability Policy Studies. https://doi.org/10.1177/1044207307311533

Schur, L., Shields, T., Kruse, D., \& Schriner, K. (2002). Enabling democracy: Disability and voter turnout. Political Research Quarterly. https://doi.org/10.2307/3088070

Sourbati, M. (2012). Disabling communications? A capabilities perspective on media access, social inclusion and communication policy. Media, Culture and Society. https://doi.org/10.1177/0163443712442702

Sudibyo, A., \& Patria, N. (2013). The Television Industry in Post-authoritarian Indonesia. Journal of Contemporary Asia. https://doi.org/10.1080/00472336.2012.757434

UNICEF. (2017). Access To the Internet and Digital Literacy.

Van Dijk, J. A. G. M. (2012). Digital democracy: Vision and reality. Innovation and the Public Sector. https://doi.org/10.3233/978-1-61499-137-3-49

Ward, A., Baker, P. M. A., \& Moon, N. W. (2009). Ensuring the enfranchisement of people with disabilities. Journal of Disability Policy Studies. https://doi.org/10.1177/1044207308325996

Yang, H. "Chris," \& DeHart, J. L. (2016). Social Media Use and Online Political Participation Among College Students During the US Election 2012. Social Media and Society. https://doi.org/10.1177/2056305115623802 